\title{
Promoting intercultural awareness among European university students via pre-mobility virtual exchanges
}

\author{
Marie-Thérèse Batardière ${ }^{1}$, Marta Giralt ${ }^{2}$, Catherine Jeanneau ${ }^{3}$, \\ Florence Le-Baron-Earle ${ }^{4}$, and Veronica $0^{\prime}$ Regan $^{5}$
}

Keywords: pre-mobility preparation; online intercultural exchanges; internationalisation.

\section{Introduction}

For more than 30 years, the Erasmus programme has given thousands of higher education students throughout Europe the chance to live and study abroad. For many, this sojourn in a foreign country is an extraordinary learning experience which enriches their language and (inter)cultural learning process. However, for others, this opportunity is undermined by cultural shock or lack of preparation.

As mentioned in Giralt and Jeanneau (2016), “[w]hile it is crucial to increase opportunities for students to go abroad, it is also paramount to prepare them for their stay in a foreign country" (p. 2781). The better prepared they are before their placement, the better their experience will be (Byram \& Dervin, 2008; Coleman, 1997). To this end, an interdisciplinary team in the School of Modern Languages and Applied Linguistics at the University of Limerick (UL) has set up multifaceted telecollaborative initiatives to equip students in advance of their period abroad. These initiatives have been brought together under the umbrella of the Ready, Mobility, Go! programme presented in the video. The latter

\footnotetext{
1. University of Limerick, Limerick, Ireland; marie.batardiere@ul.ie

2. University of Limerick, Limerick, Ireland; marta.giralt@ul.ie

3. University of Limerick, Limerick, Ireland; catherine.jeanneau@ul.ie

4. University of Limerick, Limerick, Ireland; florence.lebaron-earle@ul.ie

5. University of Limerick, Limerick, Ireland; veronica.oregan@ul.ie
}

How to cite this article: Batardière, M.-T., Giralt, M., Jeanneau, C., Le-Baron-Earle, F., \& O’Regan, V. (2019). Promoting intercultural awareness among European university students via pre-mobility virtual exchanges. Journal of Virtual Exchange, 2, 1-6. Research-publishing.net. https://doi.org/10.14705/rpnet.2019.jve.4 
serves to promote these programmes more widely to students and other stakeholders. For instance, it is included on the EURIreland website which aims to provide a first-class information service and examples of best practice for all interested in European and international education activities.

\section{Context and rationale/preparation for study abroad}

As early as 1997, Coleman stressed the importance of preparation for students to fully benefit from their experience abroad. While the practical and linguistic elements should be included in a preparatory programme, Coleman (1997) indicates that students should also develop their intercultural competence, self-awareness, and autonomy. From that point of view, as educators, it is our role to "[e]nsure that students derive as much benefit as possible from time abroad" (Savicki \& Selby, 2008, p. 349) by providing adequate and rich preparation prior to their mobility programme.

In recent years, there has been a significant increase in such initiatives (Borghetti, Beaven, \& Pugliese, 2015; Giralt \& Jeanneau, 2016; Gutiérrez, Durán, \& Beltrán, 2015; Holmes, Bavieri, \& Ganassin, 2015). This new trend of programmes brings to the fore a more formative than informative type of preparation (Gutiérrez et al., 2015), and pays special attention to the development of students' intercultural communicative competence (Borghetti et al., 2015).

In this context, the different affordances of virtual exchanges give them the potential to be used for pre-mobility programmes and more specifically to engage students in interactions with peers in their future host country. As highlighted by Kinginger (2016), “[i]n telecollaborative pedagogies, students can create social connections with their peers, see themselves through the eyes of others, [and] be exposed to specific attitudes” (p. 20).

With this in mind and in an effort to better prepare our students for their period abroad and to respond to the institutional internationalisation strategy, members of faculty at the School of Modern Languages and Applied Linguistics decided to run a series of telecollaborative projects at the UL. The Ready, Mobility, Go! initiative was developed and implemented with the collaboration of our colleagues from the Universities of León (Spain) and Louvain (Belgium).

\section{Project description}

Drawing on models of telecollaboration developed in the Cultura project (García \& Crapotta, 2007), the programme aims at raising intercultural awareness amongst pre-mobility students. It also 
facilitates language practice through online intercultural exchanges. Institutional partnerships involve undergraduate students of Spanish, French, and German in Ireland, and students of English in Spain, Belgium, France, and Germany within their specific cohorts. Participants are both language and non-language specialists. Furthermore, they come from a variety of disciplines and while preparing for their period abroad is a common goal, their profiles, needs, and mobility period timeframes often differ due to institutional specificities. During the process of establishing partnerships, reciprocity is a core principle.

As part of the project, students have to conduct a series of telecollaborative tasks in pairs or small groups over a period of four to eight weeks in the semester prior to their mobility period. The broad topics of the tasks were established after consultation with members of the International Education Division who identified a number of issues to be addressed to help students adjust to their new life abroad: information about the home and the host university, knowledge about the host country, expectations about living abroad, and comparisons of university life and academic systems in the two countries. To cover these topics, the students carry out four core tasks: (1) Introduce yourself, (2) Describe university life, (3) Discuss cultural differences, and (4) Share useful tips before leaving. The sequence of tasks is based on O'Dowd and Lewis's (2016) progressive exchange model (see Appendix for a sample of task guidelines).

\section{Impact and implications}

The project outcomes were assessed through feedback questionnaires, students' reflective portfolios, focus groups, and facilitators' diaries. The data gathered enabled the UL team to identify the following broad benefits for participants: development of intercultural awareness and digital literacy, improvement of linguistic competence, and the main aim of preparing students for the period abroad.

Results from the feedback questionnaires showed that through their exchanges of information, students gained some guidance regarding the university system (class sizes and dynamics, academic calendar, university services) as well as practical advice and insights into the target culture. The discourse analysis of the focus groups and portfolios revealed that students also received emotional support from their partners as they shared their feelings, fears or worries about living abroad. It would seem that reflection about their time abroad made students aware of the adaptation time needed and the difficulties that could arise when living in a different country (i.e. cultural adjustment). Furthermore, in many cases, the exchanges provided the students with long-lasting links with their partners as most of them continued to communicate via social media. Therefore, it 
can be concluded that the impact of this initiative went beyond its initial goals (see Giralt \& Jeanneau, 2016 for detailed results).

Over the last five years, over 200 university students have been involved in online exchanges in UL (see Table 1). The programme has expanded to include three languages and some of these exchanges are now fully integrated in the language modules of the School.

Table 1. Virtual exchange partners and number of participants

\begin{tabular}{|c|c|c|c|c|}
\hline 2014 & 2015 & 2016 & 2017 & 2018 \\
\hline $\begin{array}{l}\text { - UL - León } \\
\text { (16 students) }\end{array}$ & $\begin{array}{l}\text { - UL - León } \\
\text { (24 students) } \\
\text { - UL - UCL Louvain } \\
\text { (10 students) }\end{array}$ & $\begin{array}{l}\text { - UL - León } \\
\text { (24 students } \\
\text { Beginners, } \\
10 \text { students } \\
\text { advanced) }\end{array}$ & $\begin{array}{l}\text { • UL - León } \\
\text { (10 students) } \\
\text { • UL - Lille/Douai } \\
\text { (24 students) } \\
\text { - UL - Universidad } \\
\text { Autónoma de } \\
\text { Madrid } \\
\text { (24 students) }\end{array}$ & $\begin{array}{l}\text { - UL - Universidad } \\
\text { Autónoma de } \\
\text { Madrid } \\
\text { (86 students) } \\
\text { - UL - Paris } \\
\text { (31 students) } \\
\text { - UL - University of } \\
\text { Applied Sciences, } \\
\text { Cologne } \\
\text { (47 students) }\end{array}$ \\
\hline
\end{tabular}

\section{Conclusion}

The project Ready, Mobility, Go! is going from strength to strength since its inception in 2014. The original objectives of the project have been achieved, as student feedback shows that it has enhanced student learning on both cognitive and affective levels in terms of (inter)cultural awareness, digital literacy, linguistic proficiency, and key preparation for mobility.

It has grown in terms of student numbers, range of languages, and external partners - as announced in the video, a partnership with Germany is now included - and in some instances has been successfully integrated in the mainstream curriculum.

Due to the success and flexibility of these virtual exchanges, we intend to upscale the project by offering it systematically to UL students as an additional source of pre-mobility preparation.

It is worthy of note that a number of students involved in virtual exchanges will not spend their mobility period in the target country of their partners. This is an interesting development which points to the wider potential of online exchanges in the context of internationalisation. A project 
that started as a preparation for mobility is evolving to complement physical mobility of students or even offer the possibility of virtual mobility. This is in line with European Commission (2013) recommendations which state that "internationalisation should ensure that the large majority of learners who are not mobile [...] are nonetheless able to acquire the international skills required in a globalised world” (p. 6). Indeed, the impact of Ready, Mobility, Go! now aligns with the aspirations of the Erasmus + Virtual Exchanges (EVE) programme which advocates online intercultural learning experiences for youth who are not engaged in physical mobility. As of 2018, some of our virtual exchanges are subscribed to the EVE programme and our students are awarded a European badge for their participation.

\section{References}

Borghetti, C., Beaven, A., \& Pugliese, R. (2015). A module-based approach to foster and document the intercultural process before and during the residence abroad. Intercultural Education, 26(1), 31-48.

Byram, M., \& Dervin, F. (Eds). (2008). Student, staff and academic mobility in higher education. Cambridge Scholars Publishing.

Coleman, J. A. (1997). Residence abroad within language study. Language Teaching, 30, 1-20.

European Commission. (2013). European higher education in the world. Communication from the Commission to the European Parliament, the Council, the European Economic and Social Committee and the Committee of the Regions. COM (2013) 499 final. http://eur-lex.europa.eu/LexUriServ/LexUriServ.do?uri=COM:2013:0499:FIN:en:PDF

García, J., \& Crapotta, J. (2007). Models of telecollaboration: cultura. In R. O’Dowd (Ed.), Online intercultural exchange: an introduction for foreign language teachers (pp. 62-84). Multilingual Matters.

Giralt, M., \& Jeanneau, C. (2016). Preparing higher education language students to their period abroad through telecollaboration: the I-TELL project. AISHE-J: The All Ireland Journal of Teaching and Learning in Higher Education, 8(2), 2781-2801. http://ojs.aishe.org/index.php/aishe-j/article/view/278

Gutiérrez, G., Durán, R., \& Beltrán, F. (2015). Identifying students’ intercultural communicative competence at the beginning of their placement: towards the enhancement of study abroad programmes. Intercultural Education, 26(1), 73-85.

Holmes, P., Bavieri, L., \& Ganassin S. (2015). Developing intercultural understanding for study abroad: students' and teachers' perspectives on pre-departure intercultural learning. Intercultural Education, 26(1), 16-30.

Kinginger, C. (2016). Telecollaboration and student mobility for language learning. In S. Jager, M. Kurek \& B. O’Rourke (Eds), New directions in telecollaborative research and practice: selected papers from the second conference on telecollaboration in higher education (pp. 19-29). Research-publishing.net. https://doi.org/10.14705/rpnet.2016. telecollab2016.487

O’Dowd, R., \& Lewis, T. (Eds). (2016). Online intercultural exchange: policy, pedagogy, practice. Routledge studies in language and intercultural communication. Routledge. 
Savicki, V., \& Selby, R. (2008). Synthesis and conclusions. In V. Savicki (Ed.), Developing intercultural competence and transformation: theory, research, and application in international education. Stylus Publishing LLC.

\section{Appendix. Sample task description}

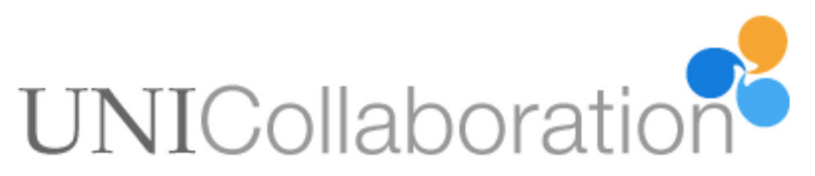

\section{6-2017}

\section{Getting Ready for your Study Abroad \\ Task sheet 4: Useful tips about living abroad}

In this task you and your partner should work together to create a document on advice and information for getting students at your universities ready for an international mobility experience: You should design together either a Word or Google Docs that includes practical information about the universities, pictures, links about local culture, and interesting cultural differences.

In your interactions together, discuss the themes in the table below and make notes on what differences you discover. Then use this list to make your document. The document should be bilingual - in both Spanish and English.

\begin{tabular}{|l|l|l|}
\hline & Ireland/The UK & Spain \\
\hline $\begin{array}{l}\text { Important things to put in your suitcase } \\
\text { before coming to our countries }\end{array}$ & & \\
\hline $\begin{array}{l}\text { Things that often surprise foreign } \\
\text { students coming to our countries }\end{array}$ & & \\
\hline Differences in lifestyle - food, timetable, prices, etc. & & \\
\hline $\begin{array}{l}\text { Differences on campus - how classes are } \\
\text { organised, teacher-student relations etc. }\end{array}$ & & \\
\hline $\begin{array}{l}\text { Places and things to see and do } \\
\text { before leaving our countries }\end{array}$ & & \\
\hline Other ideas? & & \\
\hline
\end{tabular}




\section{UNICollaboration
Journal of VIRTUAL EXCHANGE}

Published by Research-publishing.net, a not-for-profit association Voillans, France, info@research-publishing.net

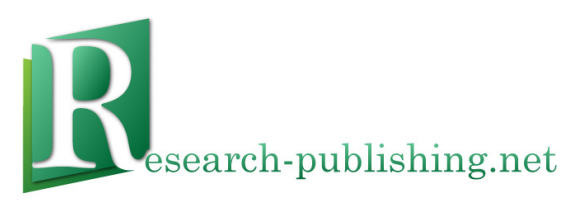

(C) 2019 UNICollaboration (collective work)

(C) 2019 by Authors (individual work)

Journal of virtual exchange 2019

Edited by Carolin Fuchs, Cecilia Kennedy, and Muge Satar

Publication date: 2019/03/25

Journal of Virtual Exchange (JVE) is an online, open-access, peer-reviewed journal aimed at practitioners and researchers in the field known variously as virtual exchange, telecollaboration, or online intercultural exchange. It is the official journal of UniCollaboration (https://www.UniCollaboration.org/), the international academic organisation dedicated to supporting and promoting telecollaboration and virtual exchange in higher-level education.

Rights. The whole volume is published under the Attribution-NonCommercial-NoDerivatives International (CC BY-NC-ND) licence; individual articles may have a different licence. Under the CC BY-NC-ND licence, the volume is freely available online (https://doi.org/10.14705/rpnet.2019.jve) for anybody to read, download, copy, and redistribute provided that the author(s), editorial team, and publisher are properly cited. Commercial use and derivative works are, however, not permitted.

Disclaimer. Research-publishing.net does not take any responsibility for the content of the pages written by the authors of this article. The authors have recognised that the work described was not published before, or that it was not under consideration for publication elsewhere. While the information in this article is believed to be true and accurate on the date of its going to press, neither UniCollaboration nor Research-publishing.net can accept any legal responsibility for any errors or omissions. Additionally, the publisher makes no warranty, expressed or implied, with respect to the material contained herein. While Research-publishing.net is committed to publishing works of integrity, the words are the authors' alone.

Trademark notice. Product or corporate names may be trademarks or registered trademarks, and are used only for identification and explanation without intent to infringe.

Copyrighted material. Every effort has been made by the editorial team to trace copyright holders and to obtain their permission for the use of copyrighted material in this article. In the event of errors or omissions, please notify the publisher of any corrections that will need to be incorporated in future editions of this article.

Typeset by Research-publishing.net

Noto fonts are open source. All Noto fonts are published under the SIL Open Font License, Version 1.1. Noto is a trademark of Google Inc. (https://www.google.com/get/noto/).

ISSN: 2647-4832 (online only) 